\title{
Heavy Metal Concentrations along the Banks of the Sitnica River and in Four Types of Herbaceous Plants
}

\author{
Albona Shala Abazi', Fatbardh Sallaku, Pajtim Bytyçii', \\ Mimoza Hyseni Spahiu ${ }^{1 *}$, Fadil Millaku \\ 1 University "Haxhi Zeka", Faculty of Management in Tourism, Hospitality and the Environment, Str. UCK, \\ Peje 30 000, Republic of Kosovo \\ 2 University "Haxhi Zeka", Faculty of Agrobusiness, Str. UCK, Peje 30 000, Republic of Kosovo \\ ${ }^{3}$ Agricultural University of Tirana, Albania \\ ${ }^{4}$ South East European University, Faculty of Contemporary Sciences and Technologies, Ilindenska 335, \\ Macedonia \\ * Corresponding author's e-mail: mimoza.hysenispahiu@unhz.eu
}

\begin{abstract}
This paper presents the results of the heavy metals accumulation $(\mathrm{Cd}, \mathrm{Cr}, \mathrm{Pb}, \mathrm{Cu}, \mathrm{Zn}, \mathrm{Mn}$, and $\mathrm{Fe})$ in soils and plants (Typha angustifolia L., Urtica dioica L., Ranunculus sardous Crantz and Rumex Crispus L.) collected along the banks of the Sitnica River, which flows through various cities of Kosovo and is quite stressed due to the discharges of urban, industrial, and agricultural pollutants. The aim of this research was to verify the accumulation of heavy metals in water, soil and plants, since vegetables that used as food are cultivated in the vicinity of sample collection. The analyses were conducted with applied methodology in the analytic laboratory of Kosovo Agriculture Institute by using MP-AES 4200 for $\mathrm{Cd}$ and $\mathrm{Cr}$, ASS-Scientific for $\mathrm{Zn}, \mathrm{Cu}, \mathrm{Fe}, \mathrm{Mn}$ and $\mathrm{Pb}$ in plant samples, whereas 4100 MP-AES was used for determination of metals in soil. The results show variations in different metal values found in the samples of the analyzed soils and plants. The lowest values accumulation of the metals analyzed were recorded at A1 (Devetak Station) near the river source and did not contain anthropogenic influences, whereas the highest values were recorded at A3 (Kuzmin Station), which belongs to the middle flow of the Sitnica River that is polluted by wastewater (urban) discharges.
\end{abstract}

Keywords: concentration, metals, plant species, soils, Sitnica River.

\section{INTRODUCTION}

The creation of nature is an undeniable phenomenon which has established all methods of preserving natural equilibrium, but the participation of human activity in different natural processes has made it necessary to apply different methods for the preservation and protection of many processes in nature [Dreshaj 2012]. Over-exploitation of nature and uncontrolled use of natural resources, including improper treatment of industrial waste, has caused the contamination of world ecosystems by toxic metals $(\mathrm{Pb}, \mathrm{Cd}, \mathrm{Cu}, \mathrm{Zn}, \mathrm{Ni}, \mathrm{Mn}$ and $\mathrm{Fe}, \mathrm{Cr}$ ) [Bilinski et al. 2010].
Heavy metals are one of the most dangerous groups due to their toxicity, concentration under natural conditions and the ability to be incorporated into the food chain [Zhang et al. 2010]. These chemical elements are usually waste products that come as a result of continuous anthropogenic industrial activities and their emission into the surrounding environment can result in contamination. Under certain environmental conditions, metals may accumulate in toxic proportions and may cause ecological damages [Shala 2015].

The accumulation of heavy metals (HMs) in natural ecosystems poses threat to human health and biodiversity due to their persistence and toxicity [Brut 2014, Singh et al. 2011, Dias and 
Nayak 2016, Sedo et al. 2017]. The heavy metal concentrations in plants are directly associated with their concentrations in soils, but their levels significantly differ among plant species, and can be even affected by genotypes within the same species [Öztürk et al. 2011].

Their concentration may vary depending on the type and they can be used as bio-indicators or bio-monitors for quality assessment in aquatic and terrestrial ecosystems [Güleryüz et al. 2008].

Historical pollution of unchecked emissions of heavy metals may persist for decades. Many studies have focused on the heavy metal accumulation capacities of terrestrial plants [González and González-Chávez 2006] and aquatic merged or submerged macrophytes [Güleryüz et al. 2008] in contaminated sites.

The Sitnica River is one of the main rivers in the Republic of Kosovo; its whole length (approximately $90 \mathrm{~km}$ ) and the catchment area are located in the territory of the Republic of Kosovo. Despite the decrease in the water quality and water levels during these years, this river was used for recreation as well as for irrigation of crops.It is a field stream and with frequent occurrences of changing the river bed from floods, this river flows through numerous settlements during its course, and in this case, considerable amounts of polluted water are discharged into its bed. In order to examine the contamination of flora and vegetation on the banks of the Sitnica River, this study has analyzed the concentration of heavy metals in four herbicidal plants: Typhaangustifolia L., Urticadioica L., Ranunculussardous Crantz and Rumex Crispus L., in four different places, which had a wide spread throughout the river flow. Soil research has been done along the course of this river as well.

The aim of this study was to investigate the concentrations of some heavy metals $(\mathrm{Cd}, \mathrm{Cr}, \mathrm{Pb}$, $\mathrm{Cu}, \mathrm{Zn}, \mathrm{Mn}$ and $\mathrm{Fe}$ ) on the soil, on the ground and underground parts of the 4 plant species that grow throughout the course of Sitnica River. The data analyzed shows that the soil samples and plants have accumulated a large amount of metal in all sampling locations. The highest concentrations for almost all of the analyzed metals were found in Kuzmin (the most striking locality wickedness from urban and industrial pollution, not to overlook the agricultural one).

This research can be useful for drafting a strategy on improving and managing the surrounding environment around the river Sitnica.

\section{MATERIALS AND METHODS}

\section{Study Area}

Sitnica River has a surface of $2.861 \mathrm{~km}^{2}$ and drains on the major part of the hollow of Kosovo. As such, it does not possess a sustainable river bank; during the floods the river covers a major part of the field along its flow, causing huge damages. Sitnica does not have a source, but with such a nomination, it starts at the place where the brook of Shtime covers the brook of Sazlis from the left hand, near the Robovc village. Topolia is considered its sourcing wing, which springs on the western hillsides of Dermanit Peak (1364 m).

From Topilla $(1280 \mathrm{~m})$ up to the estuary of Sitnica to Ibër the quote is $497.2 \mathrm{~m}$, the absolute fall is $782.8 \mathrm{~m}$ and $7.2 \%$ the relative fall [Kastrati 2014]. The river Sitnica is characterized by a quiet hydrologic regime with the average speed of flow $12.9 \mathrm{~m}^{3} / \mathrm{sec}$. [Demaku 2012].

The history shows that the establishment and development of dwellings is closely tied to the river Sitnica, and that the river represents an important factor for the development of those areas. Until lately, the river used to be a source of water for different purposes (fishing, watering and relaxing). Recently, the river Sitnica became a natural recipient of great volume of contaminated water (waters discharged from thermal power plants of Kosovo, waste waters from cities, waters of smaller dwelling areas through which the river goes) which do not have an adequate solution for their cleaning.

Undoubtedly, it can be said that the River Sitnica is endangered from numerous agricultural surfaces, dwellings with no adequate solution of avoiding or treatment of waste waters as well as important industrial departments with no adequate solution for the treatment of waters after their use at certain units [Shala, 2015].

\section{Sample site and sampling}

The sites where greater effect of pollution was expected, i.e. near the areas where urban, industrial and agriculture discharges occur, were selected for soil and herbaceous sampling.

Sampling was realized on four types of localities along the river flow (Fig. 1):

1. The first station in Devetak (referred point) an untouched area of pollution.

2. The second station in Gracka - an influenced locality of agriculture infiltration discharges. 
3. The third station in Kuzmin - an influenced locality of urban discharges.

4. The fourth station in Plementin - an influenced locality of black industrial water discharges.

From each type of them, a large number of individuals samples have been taken with the purpose to select one as representative as possible. Originally, they were washed with pure water, and then it was determined how fresh they were. The determination has been done in the field and at the Department of Biology, University of Prishtina, always based on floristic international and domestic literature. Plants have been dried naturally in a cool place (in shadow) and after the drying process the underground part of the plant was separated from the top one, and finally they were ground and weighted.

The samples of herbaceous plants have been gathered in two different time periods, i.e. in summer and autumn, and then the following parameters have been analyzed: $\mathrm{Cd}, \mathrm{Cr}, \mathrm{Pb}, \mathrm{Cu}, \mathrm{Zn}$, $\mathrm{Mn}$ and $\mathrm{Fe}$. The analyses have been conducted using applied methods in the analytic laboratory of the Agriculture Institute of Kosovo, which are referred to as effective cost analyses of large and small elements as well as stains on food products using MP - AES 4200 for $\mathrm{Cd}$ and $\mathrm{Cr}$ and ASSScientific for $\mathrm{Zn}, \mathrm{Cu}, \mathrm{Fe}, \mathrm{Mn}$, and $\mathrm{Pb}$.
The sample preparation has been conducted in accordance with A.O.A.C $17^{\text {th }}$ edition, 2000 Official Method 999.11.

The soil samples have been gathered only in the autumn, in all sites where herbaceous plants samples were taken, in the depth from $0-30 \mathrm{~cm}$ to the point where the major plant root system develops. Analyses have been performed with applied methods in the Analytical Laboratory of Agriculture Institute of Kosovo, used for determination of metals on the ground using 4100 MP-AES (Terrance hettipathirana; Agilent Technologies; Melbourne, Australia; Agriculture). The sample preparation was realized using US EPA Method 3050B (sample preparation procedure relating to the acid digestion of sediments, sludge, and soils).

\section{Statistical data analysis}

The statistical data processing was conducted using SPSS 22, the data was mirrored with the arithmetic average and standard deviation $( \pm)$. Moreover, the correlation of some metals on the ground and plants (Pearson correlation) on the scale of $95 \%$ (P 0.05) and 99\% of significance (P 0.01), was carried out. Microsoft Excel 2010 charts were used to present metals on plants statistically.

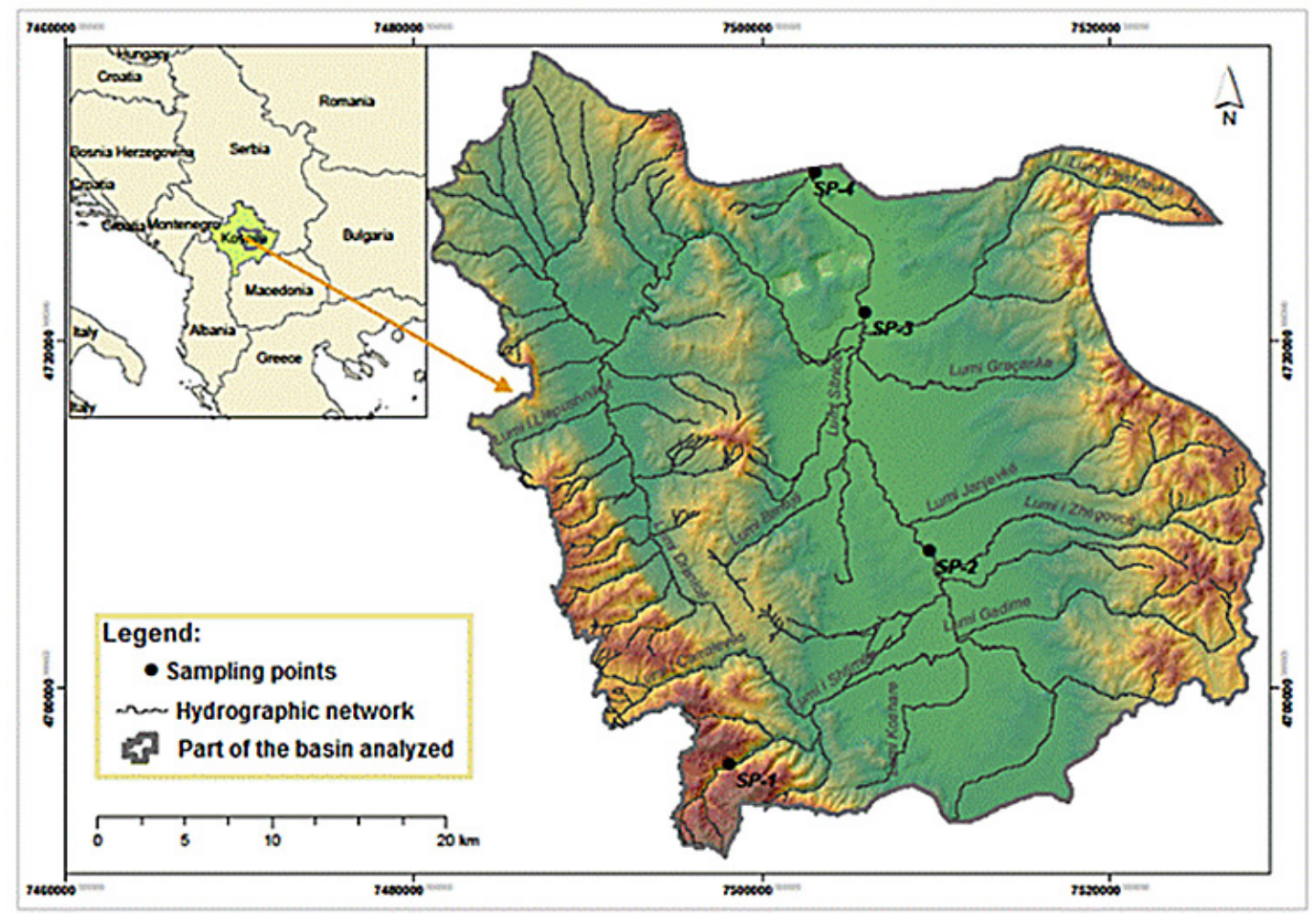

Figure 1. Location map of the study area 


\section{RESULTS AND DISCUSSION}

In order to realize the goal of the study, as well as conduct the assessment and analysis of the environmental effects along the Sitnica river flow, different representative groups of samples from environmental components were selected and analyzed, including soil $(30 \mathrm{~cm}$ depth) and herbaceous plants.

The findings of the metals content on the analyzed samples of soil along the Sitnica river flow were presented in the following table (Table 1), where the details regarding the sample sites and their code, monitoring parameters, symbols, measurement units, recorded values for every analyzed parameter and the comparison with maximal allowed values according to the domestic standards, their average values and the standard deviation can be found.

Table 1 also indicates that $\mathrm{Cd}$ in the soil samples showed the values from $0.5-1.2 \mathrm{mg} / \mathrm{kg}$. Compared to the domestic standard maximum allowed values, they were within the allowed limits in all localities. The values of $\mathrm{Cr}$ have varied from 13.1-106 mg/kg, at Vojnovc, Grcakë, Kuzmin stations, the results of $\mathrm{Cr}$ measurements have shown exceeded allowed maximum values. The variations of $\mathrm{Pb}$ range from 15.9 to $331 \mathrm{mg} / \mathrm{kg}$, when high contamination of lead is detected, the problems caused in the environment and human beings are unavoidable, particularly if humans are exposed continuously against lead or the environments with lead for long periods of time [Alushllari 2013]. The values exceeding the allowed standards of this element were found in Grackë and Kuzmin. Even the findings of Zn, at the monitoring station of Kuzmin exceeded the allowed values, according to the standards in Kosovo. The values of $\mathrm{Cu}$ varied from $11.5-50 \mathrm{mg} / \mathrm{kg}$ and have been within the allowed limits. The re- corded values for Fe varied from 566.7 to 2033.3 $\mathrm{mg} / \mathrm{kg}$, whereas for Mn they ranged from 237.5 to $1340 \mathrm{mg} / \mathrm{kg}$.

Tables 2-5 present the findings obtained from all representative samples of vegetation that were analyzed for the content of seven metals on the ground PM (stem/leaf) and underground PN (root) of four plant species, according to the samples realized during two different seasons, according to the first period (summer season) and the second period (autumn season) of monitoring, respectively.

The data from the table show that Cd during the first monitoring period in all samples of plants has been $(<0.3)$ under the detection level of the used method, while in the second monitoring period the highest value scored $0.73 \mathrm{mg} /$ $\mathrm{kg}$ on the ground surface of Rumex crispus. The lowest $\mathrm{Pb}$ values equaled $1.8 \mathrm{mg} / \mathrm{kg}$ in stem and leaves at Urtica dioica during autumn season, while the highest values reached $25.7 \mathrm{mg} / \mathrm{kg}$ on stem and leaves of Rumex crispus plant during summer. The values of $\mathrm{Cu}$ varied from $2.6 \mathrm{mg} / \mathrm{kg}$ (roots of Rumex crispus) to $14.9 \mathrm{mg} / \mathrm{kg}$ (roots of Ranunculus sardous) during the second monitoring period, respectively, in autumn. The highest values of $\mathrm{Cr}$ were recorded during the summer season $-14.8 \mathrm{mg} / \mathrm{kg}$ in stem/leaves of Rumex crispus, while the lowest value was recorded during the autumn season $-1.2 \mathrm{mg} / \mathrm{kg}$ in stem/ leaf of Ranunculus sardous. The content of $\mathrm{Zn}$ varied from 18.6 to $85 \mathrm{mg} / \mathrm{kg}$ at different plant species and at different monitoring periods.

In all plants analyzed during the two monitoring periods, $\mathrm{Fe}$ and $\mathrm{Mn}$ dominated with regards to concentration, compared to other metals. Their values were different: $\mathrm{Fe}$ ranged from 331.6 to $1928.3 \mathrm{mg} / \mathrm{kg}$ on roots of Rumex crispus during different seasons, while Mn reached $33-165.3 \mathrm{mg} / \mathrm{kg}$.

Table 1. Findings gained from the analysis of the representative soil samples

\begin{tabular}{|c|c|c|c|c|c|c|}
\hline $\begin{array}{c}\text { Metals, } \\
\mathrm{mg} / \mathrm{kg}\end{array}$ & AMV local & $\begin{array}{c}\text { Devetak } \\
\text { A1 }\end{array}$ & $\begin{array}{c}\text { Grackë } \\
\text { A2 }\end{array}$ & $\begin{array}{c}\text { Kuzmin } \\
\text { A3 }\end{array}$ & $\begin{array}{c}\text { Plemetin } \\
\text { A4 }\end{array}$ & $\begin{array}{c}\text { Average and } \\
\text { standard deviation }( \pm)\end{array}$ \\
\hline $\mathrm{Cd}$ & 2 & 0.5 & 1.2 & 1.2 & 0.6 & $1.78 \pm 2.88$ \\
\hline $\mathrm{Cr}$ & 50 & 13.1 & 57.7 & 106.0 & 98.4 & $60.08 \pm 30.92$ \\
\hline $\mathrm{Pb}$ & 50 & 15.9 & 58.0 & 331.0 & 25.0 & $210.25 \pm 393.23$ \\
\hline $\mathrm{Cu}$ & 100 & 11.5 & 40.4 & 50.0 & 38.5 & $36.53 \pm 20.22$ \\
\hline $\mathrm{Zn}$ & 300 & 23.1 & 101.9 & 361.1 & 97.2 & $206.58 \pm 287.99$ \\
\hline $\mathrm{Mn}$ & - & 237.5 & 975.0 & 1340.0 & 812.5 & $834.0 \pm 533.36$ \\
\hline $\mathrm{Fe}$ & - & 566.7 & 1733.3 & 2033.3 & 1600.0 & $1754.16 \pm 1363.35$ \\
\hline
\end{tabular}

AMV - Allowed maximal values. 
Table 2. Content of metals in vegetation at the first location (Devetak)

\begin{tabular}{|c|c|c|c|c|c|c|c|}
\hline \multicolumn{2}{|c|}{ Devetak } & \multicolumn{2}{|c|}{ Urtica dioica } & \multicolumn{2}{|c|}{ Ranunculus sardous } & \multicolumn{2}{|c|}{ Rumex crispus } \\
\hline Metals & Period & PM & PN & PM & PN & PM & PN \\
\hline \multirow{2}{*}{$\mathrm{Cd}$} & I & $<0.3$ & $<0.3$ & - & - & $<0.3$ & $<0.3$ \\
\hline & II & 0.71 & $<0.3$ & $<0.3$ & $<0.3$ & 0.73 & $<0.3$ \\
\hline \multirow{2}{*}{$\mathrm{Pb}$} & I & 8.9 & 8.7 & - & - & 25.7 & 6.5 \\
\hline & II & 1.8 & 4.3 & 4.3 & 5.6 & 4.1 & 2.6 \\
\hline \multirow{2}{*}{$\mathrm{Cu}$} & I & 6.8 & 5.4 & - & - & 6.5 & 11 \\
\hline & II & 5.7 & 4.9 & 9.1 & 14.9 & 6.1 & 2.6 \\
\hline \multirow{2}{*}{$\mathrm{Cr}$} & I & 6 & 13.5 & - & - & 14.8 & 5 \\
\hline & II & 3.4 & 10 & 1.2 & 5.6 & 5 & 3.7 \\
\hline \multirow{2}{*}{$\mathrm{Zn}$} & I & 34 & 19 & - & - & 18.6 & 29 \\
\hline & II & 19.7 & 38.1 & 72.1 & 85 & 75.7 & 40.4 \\
\hline \multirow{2}{*}{$\mathrm{Mn}$} & I & 133.7 & 123.2 & - & - & 165.3 & 149.7 \\
\hline & II & 80.27 & 71.09 & 46.8 & 75.6 & 55.1 & 33 \\
\hline \multirow{2}{*}{$\mathrm{Fe}$} & 1 & 1785 & 1543.8 & - & - & 1049.1 & 1928.3 \\
\hline & II & 332.3 & 755.8 & 575.6 & 1436.8 & 661.7 & 331.6 \\
\hline
\end{tabular}

Table 3. Content of metals in vegetation at the second location (Grackë)

\begin{tabular}{|c|c|c|c|c|c|c|c|c|c|}
\hline \multicolumn{2}{|c|}{ Gracka } & \multicolumn{2}{|c|}{ Typha angustifolia } & \multicolumn{2}{|c|}{ Urtica dioica } & \multicolumn{2}{|c|}{ Ranunculuc sardous } & \multicolumn{2}{|c|}{ Rumex crispus } \\
\hline Metals & Period & PM & $\mathrm{PN}$ & PM & PN & PM & $\mathrm{PN}$ & PM & $\mathrm{PN}$ \\
\hline \multirow{2}{*}{$\mathrm{Cd}$} & 1 & $<0.3$ & $<0.3$ & $<0.3$ & $<0.3$ & $<0.3$ & $<0.3$ & $<0.3$ & $<0.3$ \\
\hline & II & $<0.3$ & 0.22 & 0.88 & 1.03 & $<0.3$ & $<0.3$ & $<0.3$ & $<0.3$ \\
\hline \multirow{2}{*}{$\mathrm{Pb}$} & 1 & 3.8 & 8.4 & 5.6 & 6.3 & 2.8 & 3.2 & 3.9 & 7.5 \\
\hline & II & 2.5 & 9.8 & 1.8 & 6.6 & 5.4 & 4.7 & 2.4 & 7.8 \\
\hline \multirow{2}{*}{$\mathrm{Cu}$} & I & 2.4 & 3.6 & 4.7 & 4.1 & 6.8 & 4.2 & 5.8 & 5.3 \\
\hline & II & 5.2 & 13.1 & 5.1 & 2.7 & 11.3 & 14.5 & 6 & 4.7 \\
\hline \multirow{2}{*}{$\mathrm{Cr}$} & I & 1.3 & 5.2 & 4.5 & 7.9 & 5.7 & 12.6 & 4.2 & 4.3 \\
\hline & II & 0.9 & 4.8 & 5.5 & 9.3 & 1.6 & 2.9 & 2.2 & 2.9 \\
\hline \multirow{2}{*}{$\mathrm{Zn}$} & 1 & 13.7 & 12.8 & 33.9 & 14.8 & 27.5 & 13.4 & 36.7 & 29 \\
\hline & II & 16.7 & 23.1 & 38.4 & 32.9 & 94.1 & 33.2 & 72 & 30.9 \\
\hline \multirow{2}{*}{$\mathrm{Mn}$} & I & 208.3 & 116.3 & 113.7 & 191.8 & 59.3 & 130 & 60.3 & 473.4 \\
\hline & II & 180.83 & 103.5 & 243.31 & 388.16 & 53.6 & 81.9 & 37.3 & 67.6 \\
\hline \multirow{2}{*}{$\mathrm{Fe}$} & I & 290.7 & 703.5 & 452 & 1535.7 & 405.8 & 797.4 & 660.2 & 1115.9 \\
\hline & II & 104.2 & 663.1 & 470.5 & 884.8 & 407.7 & 852 & 534.8 & 701.7 \\
\hline
\end{tabular}

The findings pertaining to the metal content of the analyzed samples of four plant species in Grackë station were presented in the Table 3 provided above. In this location, there are no large urban and industrial discharges, but rather agricultural infiltrations; therefore, it is known as an agricultural location. From the data shown in the table, it can be considered that the content of the analyzed metals in the underground and surface organs varies with different values, specifically: $\mathrm{Pb}(1.8-9.8 \mathrm{mg} / \mathrm{kg}), \mathrm{Cu}$ (2.4-14.5 mg/kg), Cr (0.9-12.6 mg/kg), Zn (12.8$-94.1 \mathrm{mg} / \mathrm{kg}), \mathrm{Mn}(37.3-473.4 \mathrm{mg} / \mathrm{kg})$ and $\mathrm{Fe}$ $(104.2-1535.7 \mathrm{mg} / \mathrm{kg})$.

The highest content of the majority of metals is as follows: $\mathrm{Cd}, \mathrm{Pb}, \mathrm{Cu}, \mathrm{Cr}, \mathrm{Mn}$ and $\mathrm{Fe}$ were found in underground parts of the analyzed plants, particularly in roots, while regarding $\mathrm{Zn}$, the highest values were recorded in for ground parts (stem/leaf) of Ranunculus sardous and Urtica dioica. Even at this studied location, different values of metal concentration were noticed starting from $\mathrm{Cd}$, which was $(<0.3)$ under the detection level during the first period in all plant samples, while on the second monitoring period the highest value of it scored $1.03 \mathrm{mg} / \mathrm{kg}$ on the underground part of plant Urtica dioica.

The table above shows the highest values of $\mathrm{Fe}(107.9-2967.8 \mathrm{mg} / \mathrm{kg})$ and Mn (39.4-410.5 mg/kg) at all analyzed plants during the two monitoring periods compared to other metals. The $\mathrm{Cd}$ value, even at this monitoring station during the first period, was $<0.3$ under 
Table 4. Content of metals in vegetation at third location (Kuzmin)

\begin{tabular}{|c|c|c|c|c|c|c|c|c|c|}
\hline \multicolumn{2}{|c|}{ Kuzmin } & \multicolumn{2}{|c|}{ Typhaangustifolia } & \multicolumn{2}{|c|}{ Urticadioica } & \multicolumn{2}{|c|}{ Ranunculucsardous } & \multicolumn{2}{|c|}{ Rumexcrispus } \\
\hline Metals & Period & PM & $\mathrm{PN}$ & PM & $\mathrm{PN}$ & PM & PN & PM & PN \\
\hline \multirow{2}{*}{$\mathrm{Cd}$} & 1 & $<0.3$ & $<0.3$ & $<0.3$ & $<0.3$ & $<0.3$ & $<0.3$ & $<0.3$ & $<0.3$ \\
\hline & II & 0.55 & 0.29 & 0.84 & 0.53 & 2.56 & $<0.3$ & 0.44 & 0.73 \\
\hline \multirow{2}{*}{$\mathrm{Pb}$} & 1 & 5.1 & 13.8 & 8.2 & 15.6 & 9.1 & 4.9 & 7.6 & 10.5 \\
\hline & II & 3.8 & 60.1 & 14.3 & 24.4 & 32.8 & 33.6 & 13.1 & 8 \\
\hline \multirow{2}{*}{$\mathrm{Cu}$} & I & 2.8 & 5.7 & 5.1 & 14.3 & 11 & 6.8 & 1.9 & 3.8 \\
\hline & II & 7.3 & 14.3 & 5.6 & 5.3 & 20.5 & 14.4 & 5.4 & 4.4 \\
\hline \multirow{2}{*}{$\mathrm{Cr}$} & I & 8.4 & 84.5 & 5.7 & 12.4 & 12.5 & 13.4 & 4.8 & 8.8 \\
\hline & II & 5 & 25.1 & 16.1 & 15.1 & 18 & 15.5 & 7.8 & 10.9 \\
\hline \multirow{2}{*}{$\mathrm{Zn}$} & I & 19.3 & 24 & 33 & 83.8 & 47 & 29 & 21.3 & 34.3 \\
\hline & II & 23.6 & 18.4 & 54.9 & 61.9 & 108.3 & 65.4 & 60 & 28 \\
\hline \multirow{2}{*}{$\mathrm{Mn}$} & I & 286.4 & 410.5 & 96.8 & 114.2 & 111 & 105.6 & 46.3 & 250.3 \\
\hline & II & 177.42 & 75.23 & 94.3 & 116.7 & 309 & 78.7 & 60.5 & 39.4 \\
\hline \multirow{2}{*}{$\mathrm{Fe}$} & I & 244.3 & 1010.7 & 353.6 & 2066.6 & 595.5 & 1069.2 & 107.9 & 595.7 \\
\hline & II & 442.4 & 1008.4 & 1333.7 & 1883.5 & 2967.8 & 1657.3 & 735.1 & 703.4 \\
\hline
\end{tabular}

Table 5. Content of metals in vegetation at fourth location (Plemetin)

\begin{tabular}{|c|c|c|c|c|c|c|c|c|c|}
\hline \multicolumn{2}{|c|}{ Plemetin } & \multicolumn{2}{|c|}{ Typha angustifolia } & \multicolumn{2}{|c|}{ Urtica dioica } & \multicolumn{2}{|c|}{ Ranunculuc sardous } & \multicolumn{2}{|c|}{ Rumex crispus } \\
\hline Metals & Period & PM & PN & PM & PN & PM & PN & PM & PN \\
\hline \multirow{2}{*}{$\mathrm{Cd}$} & 1 & $<0.3$ & $<0.3$ & $<0.3$ & $<0.3$ & $<0.3$ & $<0.3$ & $<0.3$ & 0.66 \\
\hline & II & 0.28 & $<0.3$ & 10.4 & $<0.3$ & $<0.3$ & 0.72 & $<0.3$ & $<0.3$ \\
\hline \multirow{2}{*}{$\mathrm{Pb}$} & 1 & 6.8 & 31.9 & 3 & 12.5 & 3.6 & 4.9 & 10.3 & 6.7 \\
\hline & II & 4 & 5.4 & 5.4 & 4.5 & 5.4 & 10.2 & 4.8 & 9.2 \\
\hline \multirow{2}{*}{$\mathrm{Cu}$} & 1 & 4.6 & 8 & 6.3 & 0.3 & 8.6 & 2.9 & 5.9 & 5.1 \\
\hline & II & 7.4 & 2.6 & 8.6 & 5.3 & 10.6 & 13.2 & 6.1 & 6.1 \\
\hline \multirow{2}{*}{$\mathrm{Cr}$} & I & 7 & 39.7 & 4.1 & 10.4 & 5.7 & 14.9 & 6.1 & 10.5 \\
\hline & II & 3.7 & 8.5 & 5.8 & 3.8 & 9.9 & 17.8 & 3.3 & 4.3 \\
\hline \multirow{2}{*}{$\mathrm{Zn}$} & I & 19.2 & 60.1 & 28.6 & 46.5 & 43 & 14.2 & 36 & 32.6 \\
\hline & II & 18.3 & 17.6 & 50.8 & 38.6 & 65.4 & 66.2 & 42.2 & 43.8 \\
\hline \multirow{2}{*}{$\mathrm{Mn}$} & 1 & 137.4 & 206 & 41.2 & 74.9 & 45.5 & 29.9 & 43.3 & 67.5 \\
\hline & II & 260.44 & 56.16 & 72.4 & 41.3 & 69.3 & 124.4 & 46.1 & 69.3 \\
\hline \multirow{2}{*}{$\mathrm{Fe}$} & I & 666 & 2702.3 & 477.4 & 1891.3 & 790.9 & 582.7 & 500.5 & 524.1 \\
\hline & II & 484.7 & 642.3 & 688.6 & 525 & 813.5 & 1278.5 & 558.4 & 523.5 \\
\hline
\end{tabular}

the detection level of the applied method, while on the second monitoring period the highest value of it was recorded $(2.56 \mathrm{mg} / \mathrm{kg})$ in stem and leaves of Ranunculus sardous. The lowest and the highest values for other analyzed metals at Kuzmin station, located in the middle of River Sitnica and polluted by wastewater discharges, the values vary as follows: compared to the station in Grackë, the highest content of the majority of metals such as $\mathrm{Cd}, \mathrm{Cu}, \mathrm{Zn}$, and $\mathrm{Fe}$ in this station was found in the surface parts (stem and leaves), whereas, for $\mathrm{Pb}, \mathrm{Cr}$ and $\mathrm{Mn}$ the highest values were recorded in the underground parts.

In Plementin, the analyzed metals in the underground parts (roots) and surface (stem/leaves) at different plants exhibited different values that vary as follows: $\mathrm{Cd}(<0.3-10.4 \mathrm{mg} / \mathrm{kg})$ the highest value was recorded in stem and leaves of the Urtica dioica plant during the autumn season, $\mathrm{Pb}(3-31.9$ $\mathrm{mg} / \mathrm{kg}), \mathrm{Cu}(0.3-13.2 \mathrm{mg} / \mathrm{kg}), \mathrm{Cr}(3.3-39.7 \mathrm{mg} / \mathrm{kg})$ $\mathrm{Zn}(14.2-66.2 \mathrm{mg} / \mathrm{kg})$, Mn (29.9-260.4 mg/kg) and $\mathrm{Fe}(477.4-2702.3 \mathrm{mg} / \mathrm{kg})$.

In this station, the findings indicate that the highest values of the analyzed metals were found in the underground parts, particularly in roots of the vegetation, excluding $\mathrm{Cd}$ and $\mathrm{Mn}$ which had higher concentration in stem and leaves of the Urtica dioica and Typha angustifolia plants. Compared to the other stations where $\mathrm{Cd} d$ was under the detection level during the first period, in Plementin, the concentration of $\mathrm{Cd}$ during the first monitoring period in the roots of Rumex crispus is evident.

The following diagrams show the average values of the metal content level in the surface (stem/leaves) and underground parts (roots), of the analyzed plants in all locations. 


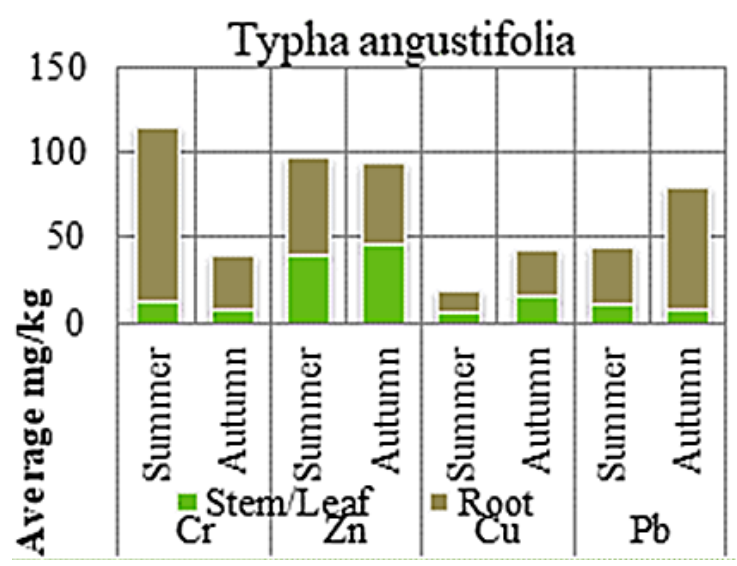

Figure 2. The average values of metals ( $\mathrm{mg} / \mathrm{kg}$ empty weight) accumulated in the samples of Typha angustifolia, during the two monitoring period.

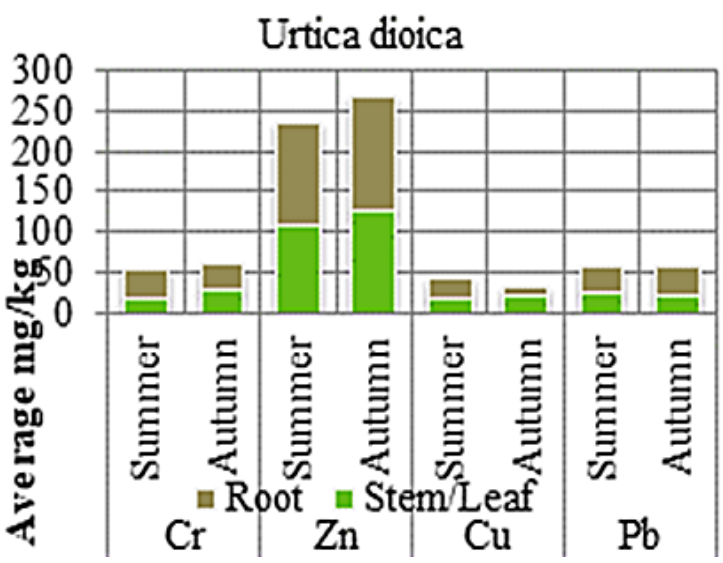

Figure 4. The average values of metals ( $\mathrm{mg} / \mathrm{kg}$ empty weight) accumulated in the samples of Urtica dioica, during the two monitoring periods.

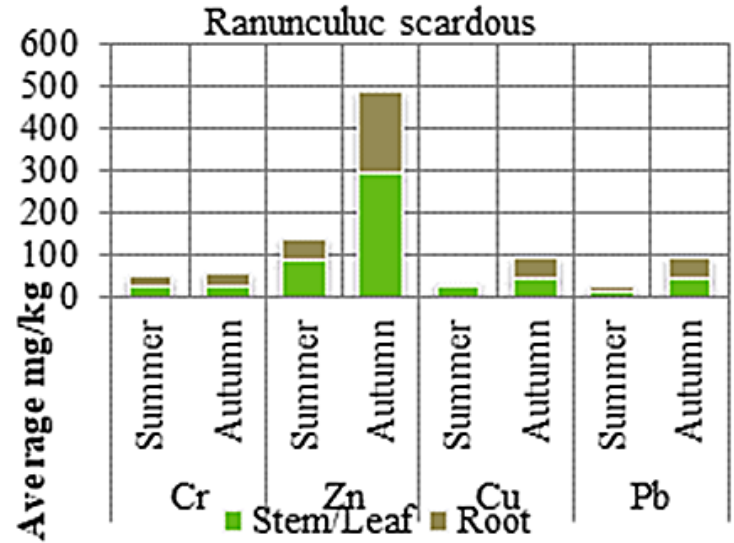

Figure 3. The average values of metals ( $\mathrm{mg} / \mathrm{kg}$ empty weight) accumulated in the samples of Ranunculus sardous, during the two monitoring periods

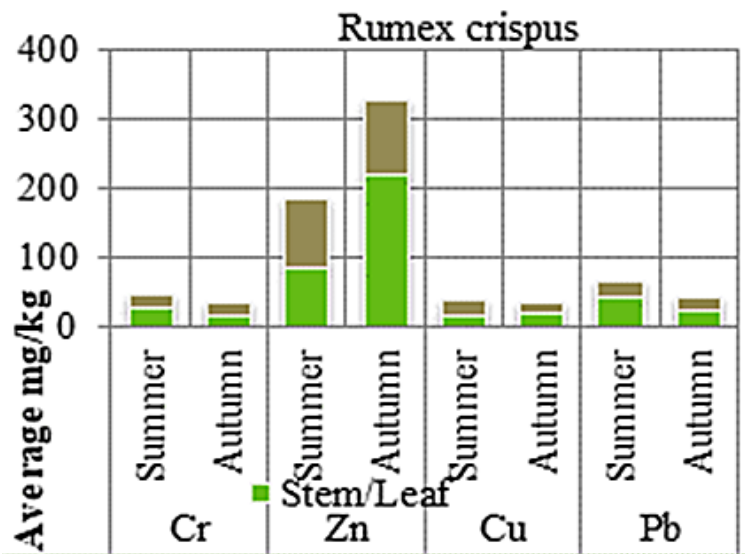

Figure 5. The average values of metals ( $\mathrm{mg} / \mathrm{kg}$ empty weight) accumulated in the samples of Rumex crispus, during the two monitoring periods

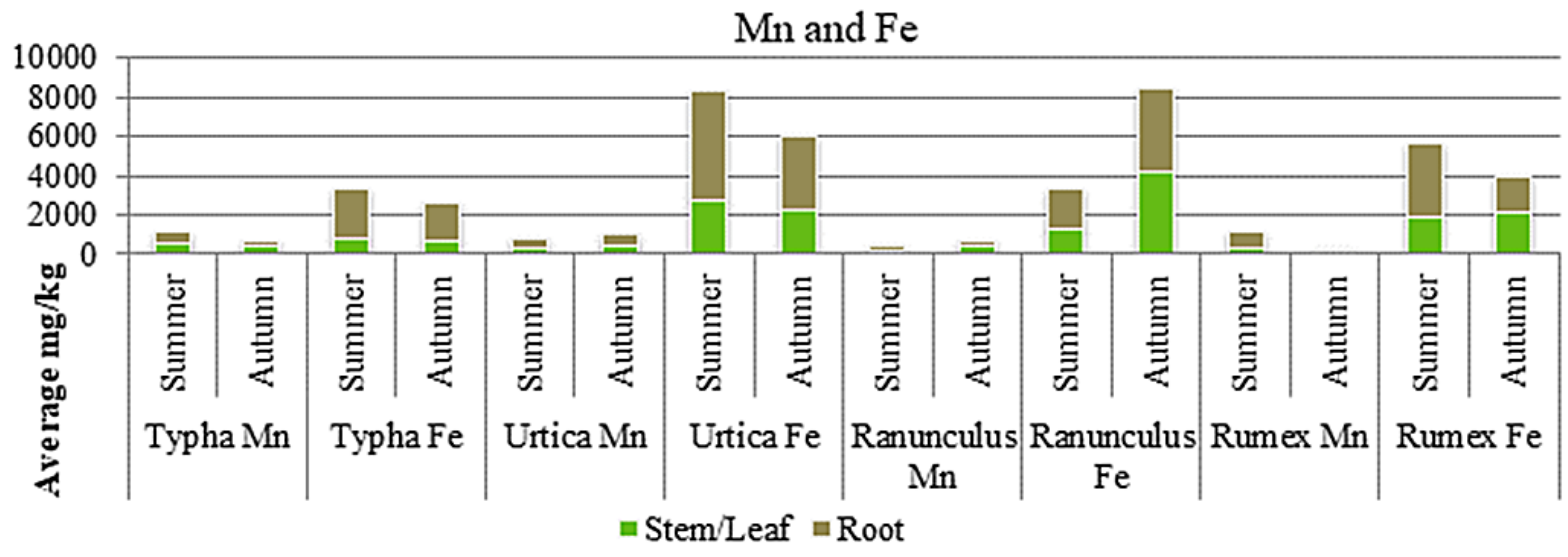

Figure 6. The average values of the $\mathrm{Mn}$ and $\mathrm{Fe}$ in the analyzed plant samples 
Table 6. Correlation of $\mathrm{Zn}, \mathrm{Mn}$, and Fe on the herbaceous plant and soil samples in the autumn season

\begin{tabular}{|c|c|c|c|c|c|c|c|c|c|}
\hline \multicolumn{10}{|c|}{$\mathrm{Zn}$} \\
\hline & TAPM & TAPN & UDPM & UDPN & RSPM & RSPN & RCPM & RCPN & Tokë \\
\hline ZnTAPM & 1 & & & & & & & & \\
\hline ZnTAPN & -.574 & 1 & & & & & & & \\
\hline ZnUDPM & .835 & -.930 & 1 & & & & & & \\
\hline ZnUDPN & ,999* & -.544 & .571 & 1 & & & & & \\
\hline ZnRSPM & .590 & .322 & .408 & .648 & 1 & & & & \\
\hline ZnRSPN & .664 & -.994 & -.320 & .269 & -.440 & 1 & & & \\
\hline ZnRCPM & -.111 & .877 & -.754 & -.202 & .285 & -.065 & 1 & & \\
\hline ZnRCPN & -.456 & -.467 & -.323 & -.533 &,$- 989^{*}$ & .523 & -.378 & 1 & \\
\hline Zn Soil & .901 & -.163 & .529 & .918 & .896 & -.063 & .045 & -.824 & 1 \\
\hline \multicolumn{10}{|c|}{$\mathrm{Mn}$} \\
\hline MnTAPM & 1 & & & & & & & & \\
\hline MnTAPN & -.783 & 1 & & & & & & & \\
\hline MnUDPM & -.569 & .957 & 1 & & & & & & \\
\hline MnUDPN & -.641 & .979 &, $996^{* *}$ & 1 & & & & & \\
\hline MnRSPM & -.484 & -.166 & -.251 & -.179 & 1 & & & & \\
\hline MnRSPN & $1,000^{*}$ & -.766 & -.318 & -.380 & -.262 & 1 & & & \\
\hline MnRCPM & -.174 & -.477 & -.746 & -.688 & .684 & -.317 & 1 & & \\
\hline MnRCPN & .573 & .061 & .476 & .418 & -.406 & .682 & -.858 & 1 & \\
\hline Mn Soil & -.957 & .568 & .422 & .491 & .765 & -.548 & .194 & -.157 & 1 \\
\hline \multicolumn{10}{|c|}{$\mathrm{Fe}$} \\
\hline FeTAPM & 1 & & & & & & & & \\
\hline FeTAPN & .363 & 1 & & & & & & & \\
\hline FeUDPM & .619 & .957 & 1 & & & & & & \\
\hline FeUDPN & .163 & .978 & .854 & 1 & & & & & \\
\hline FeRSPM & .540 & .980 & ,966* & .925 & 1 & & & & \\
\hline FeRSPN & .830 & .821 & .617 & .562 & .745 & 1 & & & \\
\hline FeRCPM & .506 & .987 & .628 & .779 & .805 & .907 & 1 & & \\
\hline FeRCPN & -.579 & .550 & .606 & .575 & .469 & -.237 & -.059 & 1 & \\
\hline Fe Soil & -.417 & .695 & .621 & .823 & .612 & -.008 & .312 & .869 & 1 \\
\hline
\end{tabular}

** Significant correlation for P 0.01 ; * significant correlation for P 0.05; TA - Typha angustifolia; UD - Urtica dioica; RS - Ranunculus sardous; RC - Rumex crispus; PM - foreground parts; PN - underground parts

\section{CONCLUSIONS}

1. The most widely spread herbaceous plants along the River Sitnica flow are: Typha angustifolia L, Urtica dioica L, Ranunculus Sardous Crantz and Rumex crispus L. The level of heavy metals concentration in the above-mentioned plants was analyzed. The data analyzed show that plants have attained a considerable quantity of heavy metals in all sampling locations. The highest concentrations for all analyzed metals $(\mathrm{Cd}, \mathrm{Pb}, \mathrm{Cu}, \mathrm{Cr}, \mathrm{Zn}, \mathrm{Mn}$, and $\mathrm{Fe})$ in plants and soil samples were found in Kuzmin (where industrial and agricultural wastewater is discharged. In contrast, the lowest values for the majority of the analyzed elements were recorded in Devetak (the station close to the river source, with no anthropogenic influences).
2. In general, Fe and Mn accumulated in the analyzed plants along the river Sitnica are found in the highest concentrations;

3. The concentration of metals, in general in Typha angustifolia and Urtica dioica plants. was higher in the underground parts (roots) during the two monitoring periods (summer and autumn), whereas in Ranunculus sardous and Rumex crispus plants - the highest content of metals during the two periods was recorded in the surface parts, particularly in stems and leaves.

4. Two out of four selected sampling sites can be considered most polluted because the values of $\mathrm{Zn}, \mathrm{Pb}$ and $\mathrm{Cr}$ analyzed in the samples are over the allowed limit and as such they pose threat. 
5. The findings suggest ample evidence regarding the level of pollution with heavy metals, soil and herbaceous plants along the flow of Sitnica river, as a consequence of the anthropogenic activity.

\section{REFERENCES}

1. Alushllari M. 2013. The environmental effect and assessment of industrial remains $(\mathrm{Pb})$ in the territory of former Battery factory, Berat. PhD Thesis Faculty of Natural Sciences, Department of Industrial Chemistry, Tirana.

2. Bilinski SF, Gashi F, Bilinsk H. 2010. Establishing of Monitoring Network on Kosovo Rivers (Drini I Bardhë, Morava E Binçës, LepencandSitnica), BALWOIS 2010-Ohrid, Republic of Macedonia.

3. Demaku S. 2012. Heavy metals as soil, water and river pollution near TC KOSOVO. PhD Thesis, Faculty of Mathematical and Natural Sciences, Department of Chemistry, University of Prishtina

4. Dreshaj A. 2012. Chemistry- environmental study of water wells Drini i Bardhë and Ibër in the Republic of Kosovo. PhD Dissertation. Faculty of Natural Sciences, Department of Environmental Industrial Chemistry, University of Tirana, 2012.

5. Öztürk E., Atsan E., Polat T. and Kara K. 2011. Variation in heavy metal concentrations of potato (Solanum tuberosum L.) cultivars. The Journal of Animal \& Plant Sciences, 21(2), Page: 235-239.
6. González R.C. and González-Chávez M.C.A. 2006. Metal accumulation in wild plants surrounding mining wastes. Environmental Pollution, 144, 84-92. Medline. DOI10.1016/j.envpol.

7. Dias H.Q. and Nayak G.N. 2016. Geochemistry and bioavailability of mudflats and mangrove sediments and their effect on bioaccumulation in selected organisms within a tropical (Zuari) estuary, Goa, India. Marine Pollution Bulletin, 105(1), 227-236.

8. Burt J.A. 2014. The environmental costs of coastal urbanization in the Arabian Gulf. City, 18(6), 760-770.

9. Kastrati B. 2014. Kosova verilindore: veçoritë fiziko-gjeografike dhe vlerësimi ekonomik i pasurive natyrore. Desertacion i doktoraturës, Tiranë.

10. Sedo K.A., Abido M.S., Salih A.A., Abahussain A. 2017. Assessing Heavy Metals Accumulation in the Leaves and Sediments of Urban Mangroves (Avicennia marina (Forsk.) Vierh.) in Bahrain. International Journal of Ecology, Vol. 2017. Article ID 3978216.

11. Singh R., Gautam N., Mishra A., Gupta R. 2011. Heavy metals and living systems: an overview. Indian Journal of Pharmacology, 43(3), 246-253.

12. Shala A. 2015. The analysis of the industrial and agricultural effects on water quality and several environmental parameters of River Sitnica, Kosovo. PhD Dissertation, UBT, Tirana.

13. Zhang H., Cui B., Xiao R., Zhao H. 2010. Heavy metals in water, soils and plants in riparian wetlands in the Pearl River Estuary, South China. Procedia Environmental Sciences, 2, 1344-1354. 